\title{
'Tombstones' in the North Italian Iron Age: Careless writers or athletic readers?
}

\author{
Ruth D. Whitehouse \\ University College London
}

\begin{abstract}
Introduction
Several different types of inscribed stone monument of the North Italian Iron Age are interpreted as funerary markers and so could be described as 'tombstones'. In the traditional classification of these monuments, the primary criterion used is the language of the inscription - Etruscan or Venetic - and the monuments assigned to the two different language groups are almost never discussed together. In this traditional scholarship, language boundaries are considered to constitute very hard edges and to correlate precisely with distinctions between archaeological cultures. A second criterion is the typology of the monuments, variously described as stelae, cippi or ciottoloni. ${ }^{1}$ What is never included in the classification process, and is rarely discussed in any detail, is the arrangement of the writing on the surface of the stone and its relationship to the iconography, where present.

This chapter examines the tombstones from a different perspective, that places the form and arrangement of the writing (rather than the language or content of the inscription) at the centre of the analysis. However, I shall begin by providing a brief description of the monuments, in order to make it easier to relate my discussion to the published literature (though, while I shall cite the most important works on the various monuments, I shall make no attempt to present a comprehensive bibliography, which is unnecessary in the present context). The map (Figure 1) shows the location of the sites mentioned in the text.
\end{abstract}

\section{The Monuments}

\section{Monuments Inscribed in Etruscan}

This section includes only those monuments found in northern Italy, in the northern extension of Etruscan territory, in the Po Valley. Stelae inscribed in Etruscan, of different types from

How to cite this book chapter:

Whitehouse, R. D. 2013. 'Tombstones' in the North Italian Iron Age: Careless writers or athletic readers? In: Piquette, K. E. and Whitehouse, R. D. (eds.) Writing as Material Practice: Substance, surface and medium. Pp. 271-288. London: Ubiquity Press. DOI: http://dx.doi. org/10.5334/bai.n 


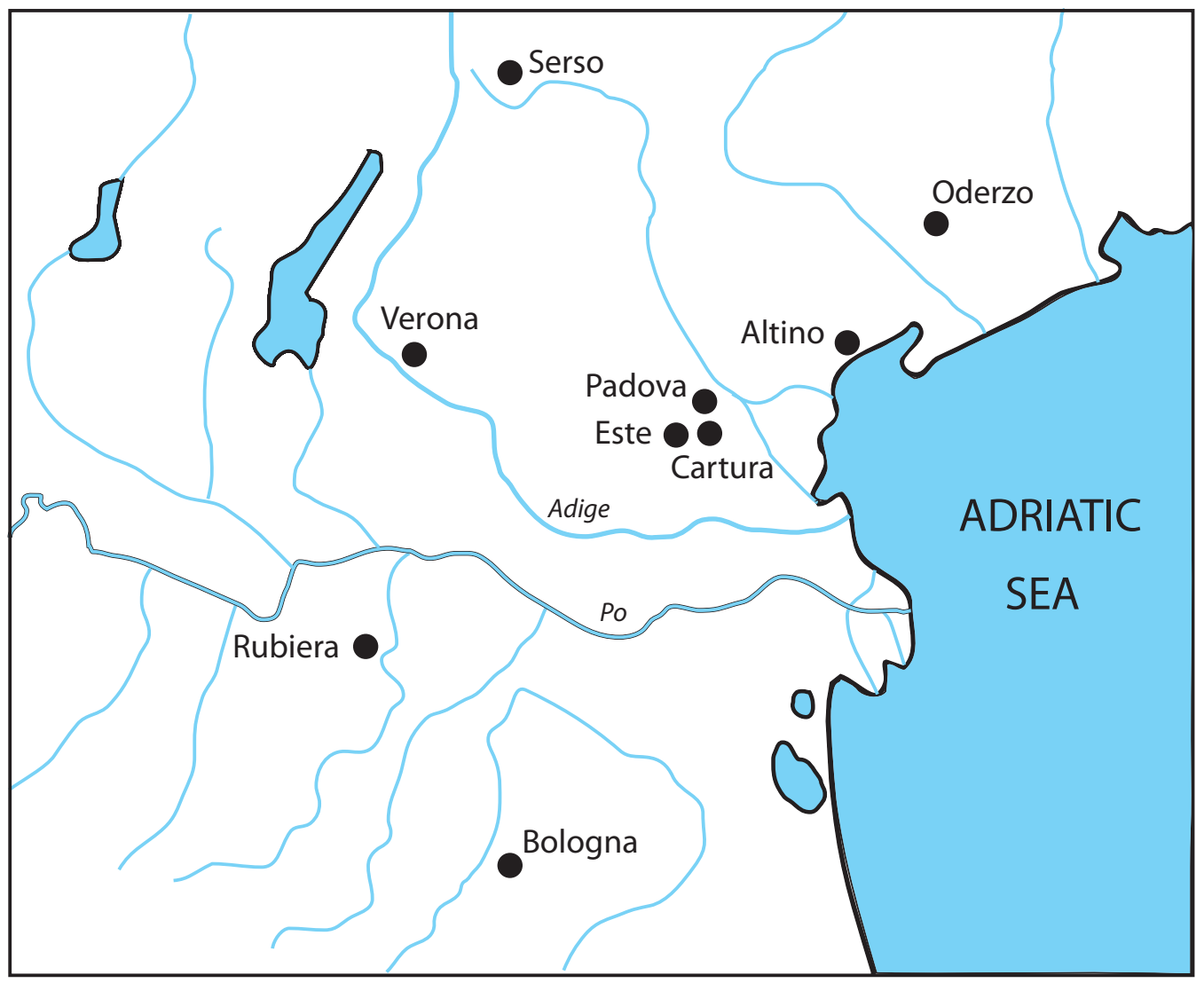

Figure 1: Map of northeast Italy showing location of main sites mentioned in the text.

those found in the north, occur on many sites throughout Etruria proper (equivalent to modern Tuscany, northern Lazio and parts of Umbria).

\section{Stelae from Bologna (Figures 2-3)}

More than 230 funerary stelae, complete or fragmentary, are known from the Villanovan and Etruscan cemeteries of Bologna (Etruscan Felsina), dating from the $8^{\text {th }}$ or $7^{\text {th }}$ century BC to the $4^{\text {th }}$ century BC (Ducati 1911; 1943; Meller Padovani 1977; Stary-Rimpau 1988). They are made of sandstone and vary in shape from generically anthropomorphic early examples to mostly horseshoe-shaped forms in the full Etruscan period. They are all decorated, carved in low relief and often originally painted, in a variety of different styles, often with figured scenes. Only 14 have inscriptions (and one of these is unreadable) and only these are included in this discussion. These inscribed stelae are dated to the $5^{\text {th }}$ (or possibly late $6^{\text {th }}$ ) and the $4^{\text {th }}$ centuries BC. Few of the monuments are complete, so it is difficult to ascertain their size range. The smallest of the complete monuments (stele 211) is $109 \mathrm{~cm}$ high while the largest (stele 10) is estimated to have been at least $270 \mathrm{~cm}$ high. The widths range from $c .60 \mathrm{~cm}$ to $c .160 \mathrm{~cm}$ and the thicknesses from $c .20$ to $44 \mathrm{~cm}$. The monuments combine iconography and inscriptions; the carved decoration occurs not only on the main surface but often continues round the sides and onto the reverse. The inscriptions are normally on the main surface, but one large stele has three inscriptions, one of which is on the back. The inscriptions are mostly horizontal and written from right to left but one rectangular 


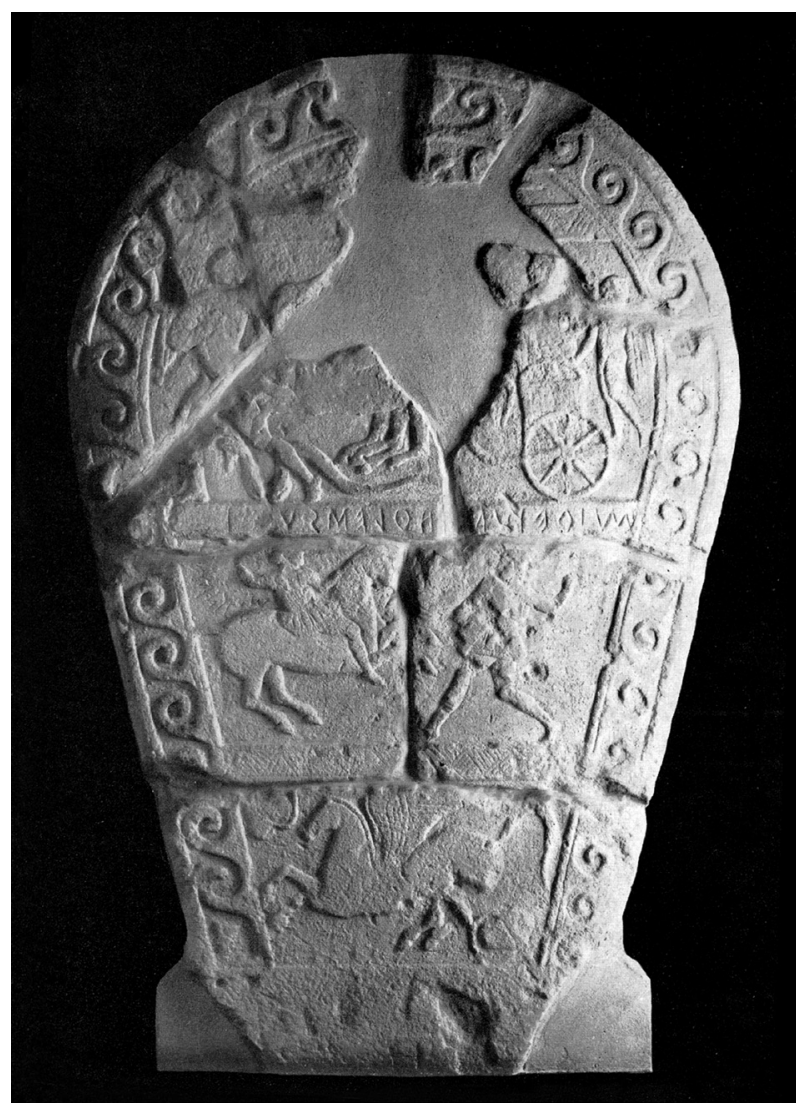

Figure 2: Bologna stele 42. Sandstone. Height: $191 \mathrm{~cm}$. The incised inscription, in Etruscan, reads from right to left. It is transliterated as mi vetus [ $k$ [athles suthi and translated as 'I am the grave of Vetu Kathle. Bologna, Museo Civico Archeologico, inv. no. Ducati 42. (c) Bologna, Museo Civico Bologna.

stele with rounded corners has an inscription round the upper edge extending round both corners. A common position for the inscriptions is in bands located between the decorative friezes.

Of all the monuments discussed in this chapter, the Bologna stelae are the most certain 'tombstones' since some have been excavated in cemeteries, including the Certosa cemetery, well known for its richly equipped tombs of the $6^{\text {th }}$ and $5^{\text {th }}$ centuries BC. The stelae were found in association with specific tombs, where they had been used as markers. The inscriptions refer to the deceased individuals and include both male and female names.

\section{Cippi from Rubiera (Figure 4a-b)}

The only other inscribed Etruscan 'tombstones' from northern Italy are two cippi found close to the Secchia river near Rubiera, on the southern edge of the Po Valley, c.50 km northwest of Bologna (De Simone 1992). The cippi were not found in an archaeological excavation and their precise context is unknown. However, the area has yielded ancient burials and it is plausible to interpret them as funerary markers. They are cylindrical in shape with rounded tops. The smaller monument (cippo 1) is $141 \mathrm{~cm}$ high and has a circumference of $115 \mathrm{~cm}$, while the larger one (cippo 2) is $170 \mathrm{~cm}$ high with a circumference of $100 \mathrm{~cm}$. Like many of the Bologna stelae, they 


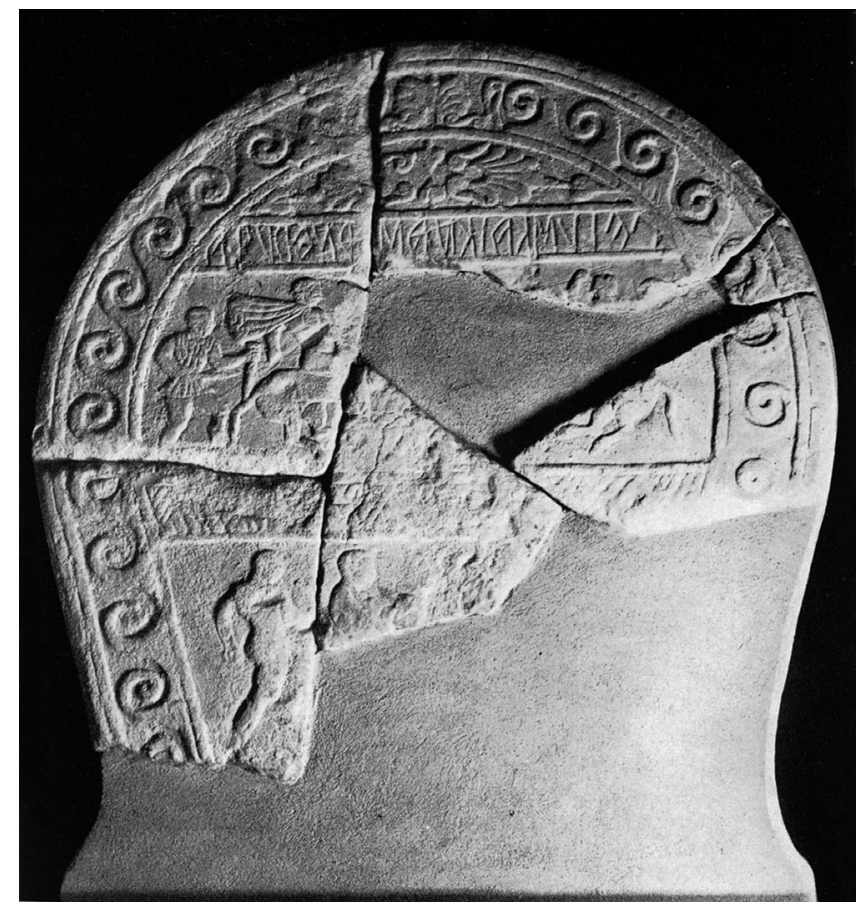

Figure 3: Bologna stele 15. Sandstone. Height: $100 \mathrm{~cm}$. The incised inscription, in Etruscan, reads from right to left. It is transliterated as velus kaiknas arnthrusla and translated as '(grave) of Vel Kaikna (son) of Arnthur'. Bologna, Museo Civico Archeologico: inv. no. Ducati 15. (c) Bologna, Museo Civico Bologna.

are decorated in low relief with orientalising motifs, but they are very different in form, with their cylindrical shape and both the decorative friezes and the inscriptions running continuously round the monument. The inscriptions are located between the decorative friezes and run horizontally, from right to left. They are dated on stylistic grounds (of both decoration and inscription) to the later $7^{\text {th }}$ century BC.

\section{Monuments Inscribed in Venetic}

Most of the funerary monuments inscribed in Venetic come from the two southern Venetic cities of Padua and Este and there are marked differences in the funerary practices of the two cities. A small number of related monuments come from other Venetic centres; here they are discussed under the headings of those from Padua and Este.

\section{Stelae from Padua (Figures 5-6)}

The characteristic form is a rectangular stone stele decorated and inscribed on one side only, made of limestone or trachyte. 15 examples are known of $6^{\text {th }}$ to $4^{\text {th }}$ (or early $3^{\text {rd }}$ century) BC date, from different locations in the city of Padua (Padova), of which eight bear legible inscriptions in Venetic (Fogolari 1988; Prosdocimi 1988; Zampieri 1994), while a further example of the $1^{\text {st }}$ century BC is inscribed in Latin (Lomas 2006; Zampieri 1994). Two others of a related type are known: one from Monselice and one from Altino (Figure 7; Martini Chieci Bianchi and Prosdocimi 1969; Scarfi 

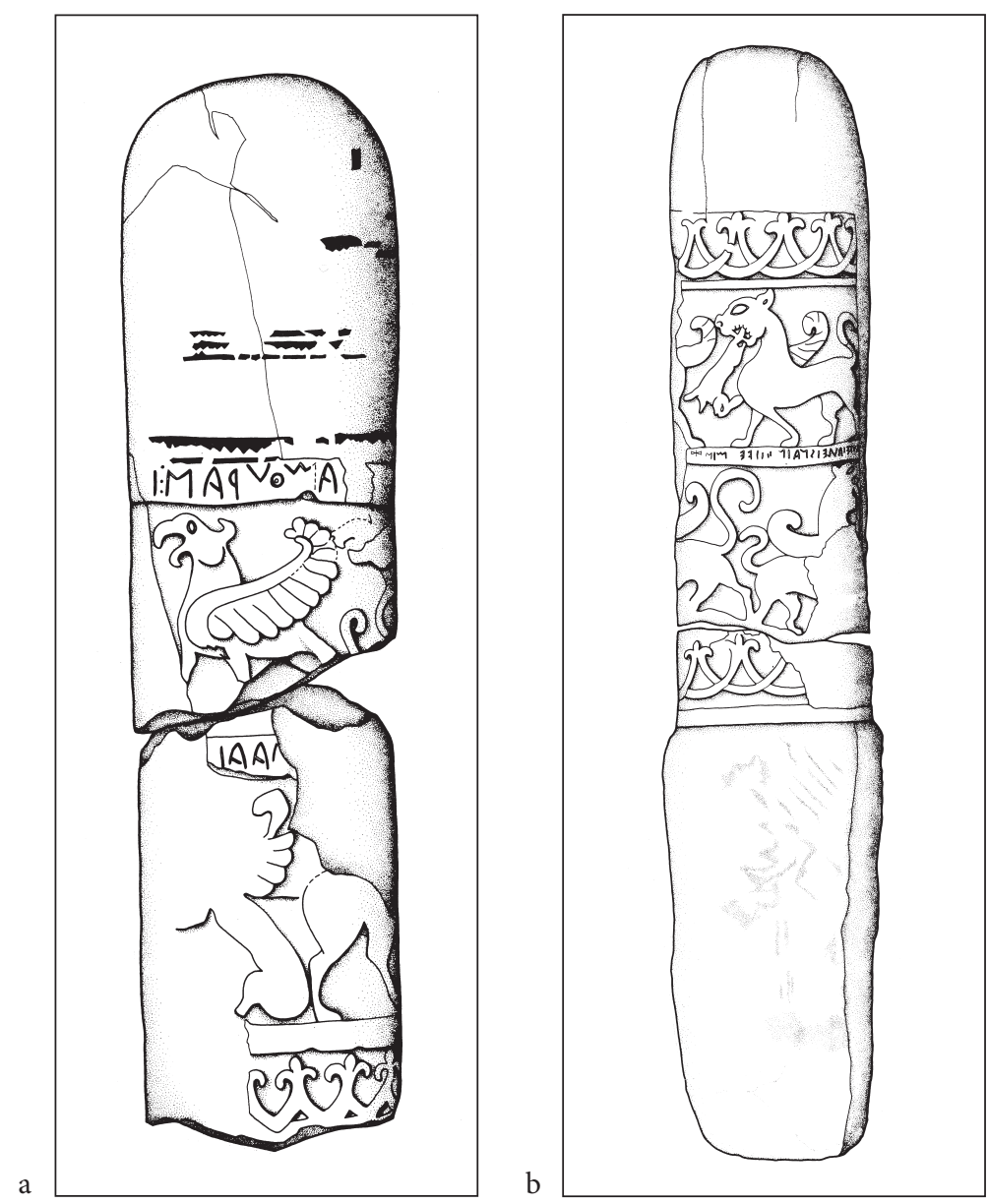

Figure 4: Rubiera stelae, Et Pa 1.1 and Et Pa 1.2. a) Sandstone. Height: $141 \mathrm{~cm}$. The incised inscription, in Etruscan, reads from right to left and runs round the circumference of the stone. It is transliterated as mi aviles amthuras ima ame [---]eius lqr b) [---]ma al[---] and translated as 'I am of Avle Amthura ????'; b) Sandstone. Height: $177 \mathrm{~cm}$. The incised inscription, in Etruscan, reads from right to left and runs round the circumference of the stone. It is transliterated as kuvei puleisnai mi isive [---] mise [---] mulvlenke zilath mi salalati amake; the translation is disputed but seems to involve two people, one female (Kuvei Puleisnai) and a second, assumed to be male, who was zilath at a place called either Misala or Sala. Reggio Emilia, Musei Civici (after De Simone 1992: Tav. 1).

1969-1970; Zampieri 1994). None have been found in situ but they are assumed to have been set into the ground as tomb markers; this assumption is supported by the fact that in many cases the bottom of the stone was left rough and was presumably not intended to be visible. The monuments are quite small: only one is more than a metre high, the one from Altino, which has a height of 115 $\mathrm{cm}$. The others range in height from 54 to $95 \mathrm{~cm}$, while widths range from 45 to $69 \mathrm{~cm}$. They have a central reserved panel on the upper part of the stone containing a scene incised or carved in low relief. The inscription runs round the panel taking up one, two, three or four sides; each is written from right to left, except for the $1^{\text {st }}$-century example in Latin, which is written from left to right. 


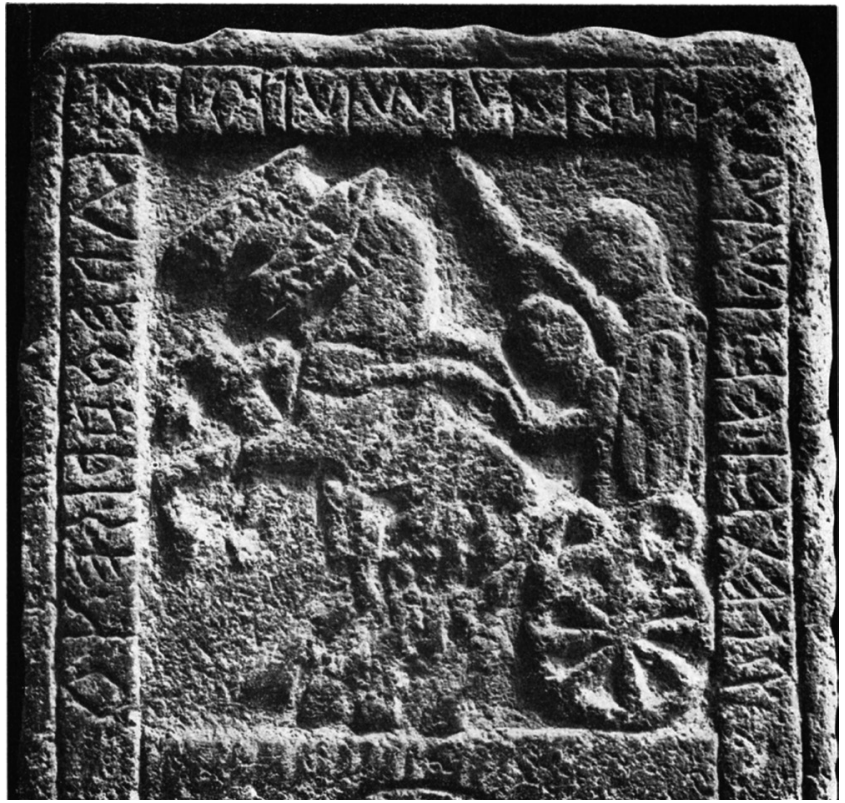

Figure 5: Padua stele, Pa2. Trachyte. Height: $86 \mathrm{~cm}$. The incised inscription, in Venetic, reads from right to left, starting in the bottom right corner and running round three sides of the relief carved figured panel. It is transliterated as mi aletei veignoi karamniioi ekupetaris ego and translated as 'I am to Aletes Veignos Karamniios the ekupetaris' or 'I am the ekupetaris to Aletes Veignos Karamniios'. Verona, Museo Lapidario Maffeiano: inv. 28741.

\section{Cippi from Este (Figures 8-9)}

These cippi are small obelisk-shaped (pyramidal) stones, mostly made of trachyte, some of which bear inscriptions but no iconography. Cippi, of which there are also many uninscribed examples, may have been set up outside a group of tombs or a tumulus covering several tombs and are thought to mark a kinship group rather than individual burials (Balista and Ruta Serafini 1992; Fogolari 1988: 99-105; Marinetti 1988: 136-137, 147-149; Prosdocimi 1988: 247-259). They are mostly dated to the $5^{\text {th }}$ and $4^{\text {th }}$ centuries $\mathrm{BC}$, though their use could begin as early as the late $6^{\text {th }}$ century and go on as late as the $3^{\text {rd }}$ century. Twenty-four typical inscribed examples are known while there are also three stelae of other forms. Like the Paduan stelae, the stones often have rough bases presumably intended to be set in the ground and therefore not visible. They average 50-60 $\mathrm{cm}$ in height, while the largest is $150 \mathrm{~cm}$ tall and the smallest only $c .30 \mathrm{~cm}$. They are normally rectangular rather than square in section, measuring from $c .14 \times 20 \mathrm{~cm}$ to $31 \times 40 \mathrm{~cm}$ above the rough base, reducing in dimensions towards the top. The inscriptions run vertically in one, two or three lines, in boustrophedon form when there is more than one line. Most cippi have inscriptions on one face only, but three have two adjacent sides inscribed.

\section{Ciottoloni from Padua (Figures 10-11)}

The ciottoloni are natural pebbles of glacially smoothed Alpine porphyry, with maximum dimensions ranging from 16 to $46 \mathrm{~cm}$. They were probably used as funerary markers, although few have been found in any meaningful context. There are 18 examples incised in Venetic, of which 17 come from the territory of Padua or close by, while one comes from Oderzo; a further example 


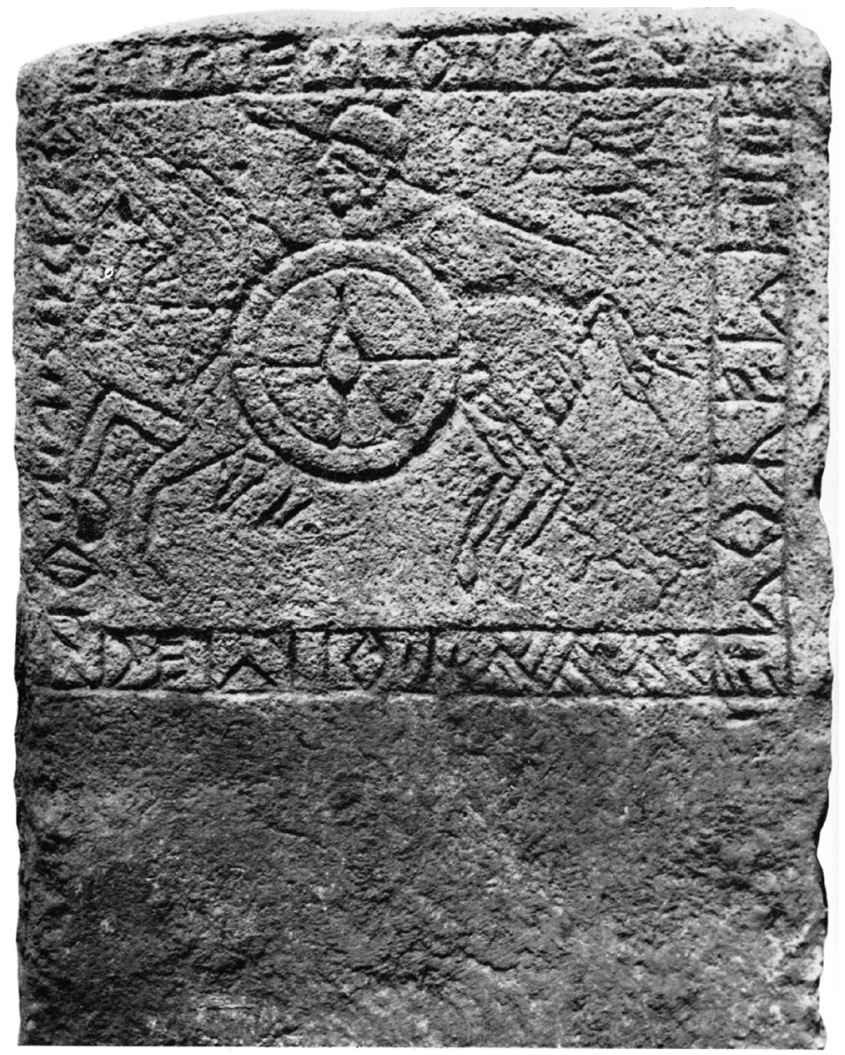

Figure 6: Padua stele, Pa3bis. Trachyte. Height: $90 \mathrm{~cm}$. The incised inscription, in Venetic, reads from right to left, starting in the bottom right corner and running round four sides of the incised figured panel. It is transliterated as enogenei enetiioi eppetaris albarenioi and translated as 'to Enogenes Enetios Albarenios the ekupetaris' or '( $\mathrm{I}$ am) the ekupetaris to Enogenes Enetios Albarenios'. Padova, Museo Civico. (C) Assessorato alla Cultura, Comune di Padova.

comes from Serso and is inscribed not in Venetic but Raetic (found in the area northwest of the Venetic region). The inscriptions are mostly short but a few are longer; they tend to run round the longer circumference of the stone although more complicated arrangements also occur, including one figure-of-eight design. They lack any iconography except for one example of a stylised key design, which appears on the example with the inscription in the form of a figure-of-eight (Figure 11). They are often attributed dates from the $6^{\text {th }}$ to the $1^{\text {st }}$ centuries $\mathrm{BC}$ on a mixture of linguistic and general associational criteria, although none very secure. Calzavara Capuis et al. (1978: 188-190) have argued for an early date (mid $-5^{\text {th }}$ century вС or earlier) for all the ciottoloni on the basis of name-forms, palaeography and the archaeological context of one example from Piovego.

\section{The Cartura Stone (Figure 12)}

A unique monument found near Cartura, on the border between the territories of Este and Padua, is sometimes considered a variant of the ciottolone class, but is in fact quite distinctive. Unlike the ciottoloni, it is made of limestone and is not a natural pebble but has been worked into shape. It is oval in form but has a flat top and bottom and straight sides with bevelled edges at top and bottom (it is sometimes colloquially known as 'the cheese' because of its shape). It measures $27 \times 17$ 


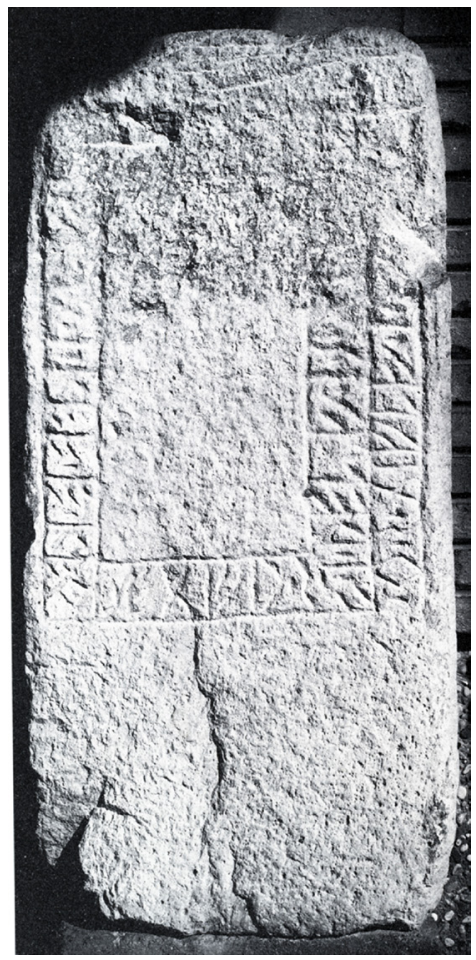

Figure 7: Altino stele, Tr7. Trachyte. Height: $115 \mathrm{~cm}$. The incised inscription, in Venetic, reads from right to left; although the top part is badly damaged it is possible to see that it originally had 6 lines, starting in the bottom right corner and arranged in a spiral pattern, with line 5 inside line 1 and line 6 inside line 2. It is transliterated as ostialai $A[----|---|---]$ naikve ekvopetars | fremaist[---- | ----ia]bos and translated as 'to Ostiala a[-------] and [-------] na Freimast[-----] the ekupetaris' or 'Funerary monument to Ostiala a[-------] and for [------] na, Fremaist[----]'. Altino, Museo Archeologico Nazionale: inv. AL 11732. Published with the permission of Ministero dei beni e delle attività culturali e del turismo; reproduction prohibited.

$\mathrm{cm}$ and has a height of $100 \mathrm{~cm}$. This stone bears one of the longest and most complicated of all the Venetic funerary inscriptions, with eight words, running right to left round the upper edge of the circumference of the stone. It is dated to the $6^{\text {th }}$ century $\mathrm{BC}$, among the earliest of the Venetic inscriptions. However, the stone was found without archaeological context and the dating is based on letter form and the absence of punctuation - an inherently weak basis, as John Wilkins and I have argued elsewhere (Whitehouse and Wilkins 2006: 542-543).

\section{Other Monuments}

There are a few other stone monuments that appear to have been used as funerary markers in the Venetic centres; these are stelae or cippi of various shapes, some quite irregular, and do not fall into any clear class. They are excluded from the present discussion. 


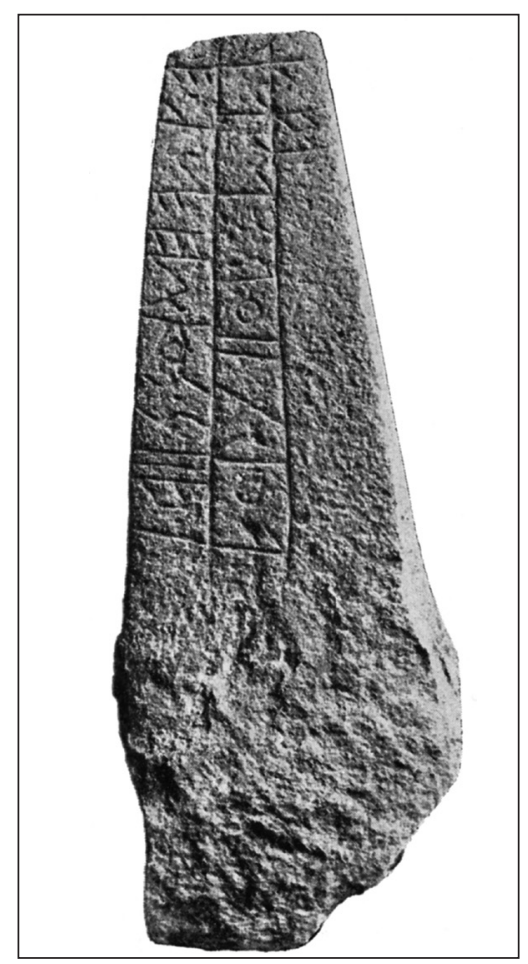

Figure 8: Este stele, Es2. Trachyte. Height: $64.5 \mathrm{~cm}$. The incised inscription, in Venetic, reads from right to left, starting in the top left corner and running first down, then up, then down again. It is transliterated as ego fukssiai voltiommninai and translated as 'I am (the tomb) to Fukssia Voltiomnina'. Este, Museo Nazionale di Atestino. Published with the permission of Ministero dei beni e delle attività culturali e del turismo; reproduction prohibited.

\section{The Inscriptions}

\section{The Content of the Inscriptions}

I do not propose to discuss the content of the inscriptions in any detail here, since they are not the focus of my study. However, it is worth noting that they represent the aspect of the tombstones that demonstrates the greatest similarity, transcending the major differences of language (Etruscan or Venetic) and of form of monument (stele, cippus or ciottolone). Because they are formulaic in nature and characteristically short, often two or three words only and very rarely more than six, they are frequently translated with confidence. However, in fact neither language is fully understood and there is much debate among linguists about both syntax and lexicon. Nonetheless we can see that most inscriptions include a one- or two-part name, assumed to be that of the owner of the tomb being marked; in the Etruscan inscriptions the name appears in what is taken to be the genitive case, while the Venetic ones are in what is taken to be the dative. Both male and female names appear. While many of the inscriptions consist of the name alone, others take the form of so-called 'talking inscriptions', beginning in the Etruscan examples with 'mi', in the Venetic with 'ego'. In a small number of cases, in both Etruscan and Venetic, a term is used that is interpreted as relating to either an office held by the deceased, or to a status or class. In Etruscan the term is 'zilath', usually interpreted as a magistracy; in Venetic the term is 'ekupetaris' (and variants), sometimes interpreted as referring to membership of an equestrian class or, more 


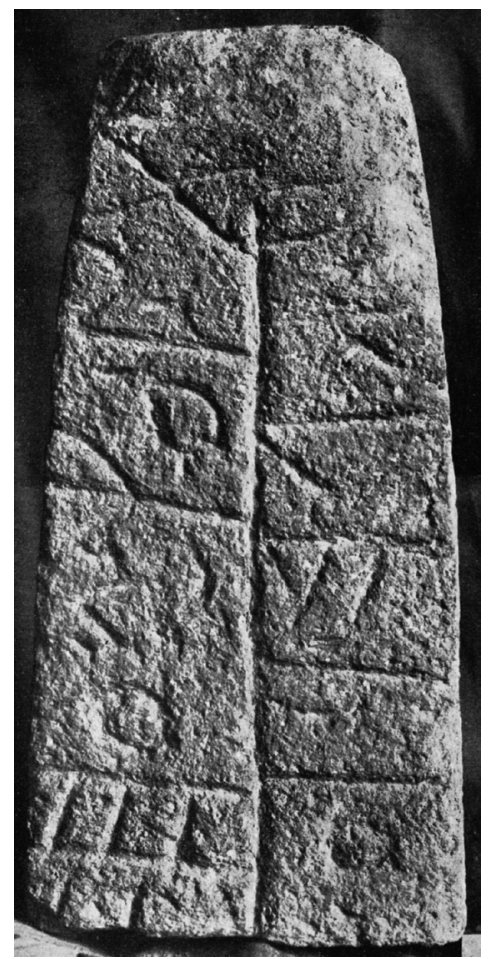

Figure 9: Este stele, Es13. Trachyte. Height: $29 \mathrm{~cm}$. The incised inscription, in Venetic, reads from left to right, starting in the bottom left corner and running first up, then down. It is transliterated as fougonte[i urk]leoi (ego may be missing) and translated as '(I am the tomb) to Fugontes Urkleos'. Este, Museo Nazionale di Atestino. Published with the permission of Ministero dei beni e delle attività culturali e del turismo; reproduction prohibited.

specifically, as meaning a charioteer. In some of the Etruscan examples the term 'suthi' appears and is interpreted as meaning 'grave'.

Examples of Etruscan inscriptions (transcribed and translated) are:

- pesnas kathles salchis of Pesna Kathle (Bologna stele 47)

- mi suth i thanchvilus titlalus I (am) the grave of Thanchvil, (daughter) of Titlalu (Bologna stele 105)

- [-----]as' levels zilacnuk[e] [I am the grave of ????? ????]as', son of Leve, who was zilath (Bologna stele 25, inscription a)

Examples of Venetic inscriptions (transcribed and translated) are:

- hostihavos toupeio to Tihavos Toupeio (Padua ciottolone Pa7)

- ego voltiomnoi iuvantioi I am to Voltiomnos Iuvantios (Este cippus Es4)

- aletei veignoi karamniioi ekupetaris ego I am to Aletes Veignos Karamniios, the ekupetaris (Padua stele Pa2)

\section{Arrangement of the Inscriptions}

In contrast to the content of the inscriptions, which are repetitively similar, their arrangement on the tombstones demonstrates marked differences. In this section I shall describe the main variants 


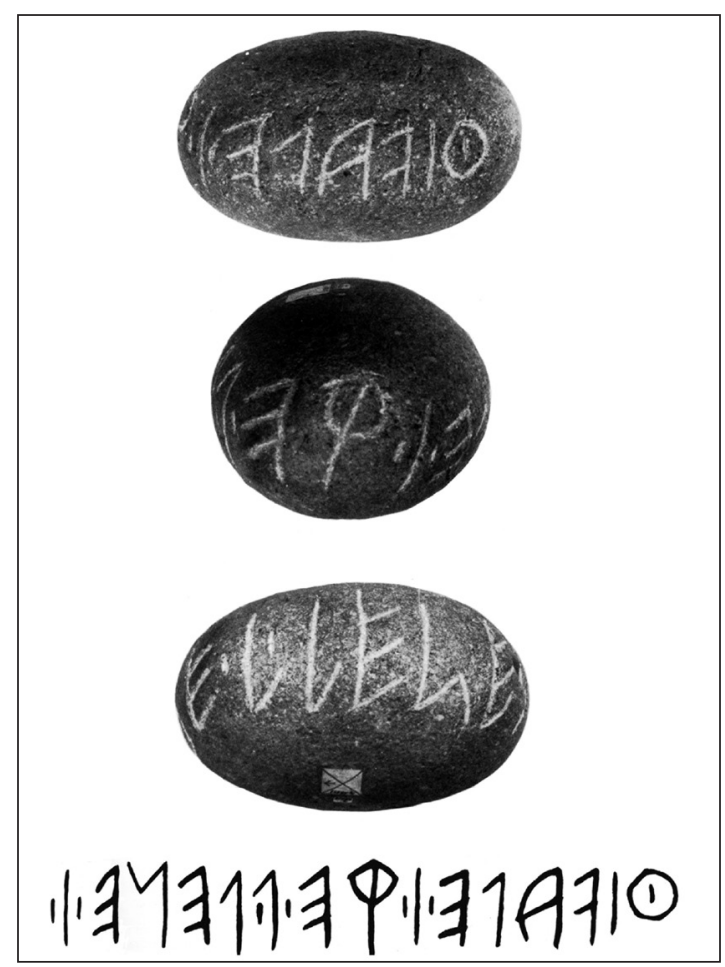

Figure 10: Padua ciottolone Pa25. Porphyry. Dimensions: $23 \times 17 \times 14 \mathrm{~cm}$. Photographs taken from different sides of ciottolone with transcription of complete inscription. The incised inscription, in Venetic, reads from right to left and runs round the circumference of the stone. It is transliterated as tivalei bellenei and translated as 'to Tivales Bellenios'. Museo di Scienze Archeologiche e d'Arte dell'Università di Padova. Published with the permission of Ministero dei beni e delle attività culturali e del turismo; reproduction prohibited.

and indicate the implications for the reader (I shall turn to the writer later). I assume here that the reader would have encountered the stone in its fixed position on or by the tomb and would have had to move his or her eyes, head, or body, to read the inscription.

\section{Inscriptions in Horizontal Lines on a Flat Surface}

Inscriptions in horizontal lines occur on the majority of the Bologna stelae, inscribed in Etruscan, where they are characteristically placed in bands running between the zones of decoration (Figures 2-3). This is the variant that most resembles modern tombstones, in that it requires the reader to stand in front of the monument, involving movement only of the eyes, or perhaps slight movements of the head (though from right to left, in contrast to the direction of modern western writing). What is different from most modern tombstones, however, is the subservient relationship of the writing to the decoration: in most of the Bologna stelae the inscriptions are not very large, with a maximum letter height of $c .8 .0$ or $9.0 \mathrm{~cm}$, and the figured scenes dominate the visual impression.

\section{Inscriptions in Horizontal Lines Around the Circumference of the Stone}

Different versions of horizontal inscriptions occur on the two Rubiera cippi, written in Etruscan (Figure 4a-b). They resemble the Bologna stelae in that the inscriptions are located in horizontal 


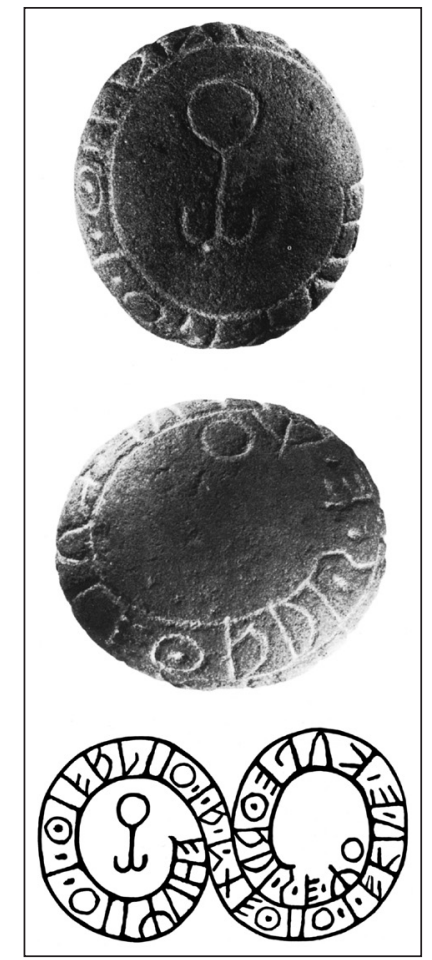

Figure 11: Padua ciottolone Pa26. Porphyry. Dimensions: $25.7 \times 23 \times 17 \mathrm{~cm}$. Photographs taken from different sides of the ciottolone and transcription of complete inscription. The incised inscription, in Venetic, reads from left to right and runs round the circumference of the stone in a figure-of-eight configuration. It is transliterated as fugioi tivalioi andetioi ekupetaris ego and translated as 'I am to Fugios Tivalios Andetios the ekupetraris' or 'I am the monument to Fugios Tivalios Andetios'. Este, Museo Nazionale di Atestine: inv. IG 145813. Published with the permission of Ministero dei beni e delle attività culturali e del turismo; reproduction prohibited.

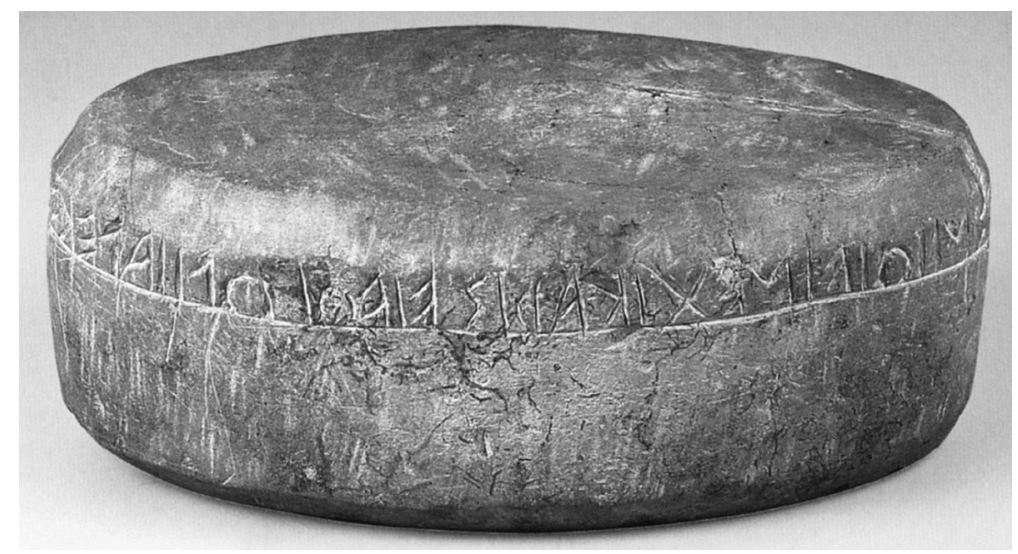

Figure 12: The Cartura stone Es122. Limestone. Dimensions: $27 \times 17 \times 10 \mathrm{~cm}$. The incised inscription, in Venetic, reads from right to left and runs round the circumference of the stone. It is transliterated as ego fontei ersiniioi vinetikaris vivoi oliialekve murtuvioi atisteit and translated as 'I am to Fontis Ersinios; the vinetikaris set this up (to him) whether living or dead'. Este, Museo Nazionale Atestino: inv. IG 41528. Published with the permission of Ministero dei beni e delle attività culturali e del turismo; reproduction prohibited. 
bands separating zones decorated with figured scenes. However, unlike the Bologna stelae, the monuments are cylindrical in shape and both the decorative friezes and the inscriptions run right round the stones. To read the inscriptions fully, the reader would have to walk round the stones in a clockwise direction (since the direction of writing is again right to left).

Very different in form from these cippi are the ciottoloni from Padua, inscribed in Venetic (Figures 10-11), but they also, in most cases, have inscriptions running round the circumference of the stone, as does the unique Cartura stone (Figure 12). They are mostly written from right to left, but a few run left to right. Although these stones are not large (none exceeds $50 \mathrm{~cm}$ in their longest dimension), they would nonetheless have required the reader to walk round them to read the full inscription. Moreover, if they were placed directly on the ground surface - and we have no evidence on this one way or the other - an adult reader would also have had to bend or kneel to read them.

Inscriptions written around the circumference of a stone can pose an additional problem for the reader, in those cases where there is no gap in the text - which is to identify where the beginning is. The formulaic nature of the inscriptions means that this can usually be assessed plausibly possibly more easily by the original reader than the modern linguist - but it would nonetheless have to be sought and would not have been obvious at first sight.

\section{Inscriptions in Straight Lines Around the Sides of a Figured Panel}

Inscriptions around the sides of a figured panel occur on the stelae from Padua, Monselice and Altino (Figures 5-7), all but one inscribed in Venetic, one in Latin. The Venetic examples run right to left, the Latin one left to right. Of those where the inscription can be read or reconstructed reasonably completely, two run along the top only, three run around two sides, two along three sides, two along four sides, while one - the example from Altino with an empty panel where the figured scene normally occurs - consists of six lines arranged in a spiral fashion (Figure 7). The one- and two-line inscriptions begin at the top, in the Venetic examples starting in the top righthand corner, in the Latin example in the left-hand corner; the three- and four-line inscriptions all begin on the right side starting in the bottom right-hand corner. The six-line inscription also begins in the bottom right-hand corner and is arranged in a spiral fashion, with line 5 wrapping round inside line 1 and line 6 wrapping around inside line 2 along the top of the stone. All the inscriptions are written as if inscribed on a continuous baseline, with the letters aligned with their tops towards the edge of the stone and the bottoms facing inwards. In the case of the four- and six-line inscriptions, this means that the bottom (fourth) line is upside down in comparison to the top (second) line.

For the reader, these inscriptions require considerably more movement of the head than horizontal inscriptions do. (S)he must first lean to the right to read line 1, straighten up to read line 2 across the top, then lean to the left to read line 3 . To read line 4 , where present, the reader must be able to read upside down writing (or stand on his or her head).

A single example of the Bologna stelae, inscribed in Etruscan, presents a variant of this type. The fragmentary stele 137 seems to have had a three-sided inscription around the top of the stone, running right to left as usual, but in this case the corners are rounded, so the inscription is curved at both ends.

\section{Inscriptions in Vertical Lines}

Inscriptions in vertical lines occur on the cippi from Este, inscribed in Venetic (Figures 8-9). The necessity to place the inscriptions vertically is created by the choice of small obelisk-shaped monuments as tombstones: the narrow widths would not accommodate more than three or four letters on a line, which would be impractical for the length of inscriptions required. Even exploited 
lengthways, the inscriptions mostly require two lines and in two cases, three. In two further cases, the inscription occupies two adjacent faces of the stone, creating one further three-line (Es137) and one four-line inscription (Es8). One other stone (Es9), with inscriptions on two faces is normally treated as bearing two separate two-line inscriptions. The multi-line inscriptions are all written boustrophedon, usually but not always starting at the top of the stone in the left-hand top corner, with the second line running upwards and the third, where present, down again. Two different arrangements occur. Some inscriptions are written as sitting on separate baselines, so that the letters are all the same way up and the first line reads right to left and the second left to right. Others, however, are written as on a continuous baseline, so that the letters of the second line are upside down in relation to those on the first. These two different arrangements impose different movements on the reader: for the first type (s)he has to alternate movements of the head to the left, then right, while for the second type the whole body has to be repositioned to read the second line and then again for the third line, where present. It is worth pointing out that reading inscriptions arranged vertically, while perfectly possible, is never particularly easy. In the case of the Este cippi, which rarely stand more than half a metre high above ground level, adult readers would have had to bend down, or even kneel, as well as move their heads from left to right. In the case of the three cippi that are inscribed on two adjacent sides, the reader would also have to move bodily to read the second side.

\section{Inscriptions in Elaborate Arrangements}

Two of the ciottoloni have inscriptions in more elaborate arrangements. One (Figure 11) has an inscription written left to right in a figure-of-eight configuration. This is also the only ciottolone to have any decoration: an abstract key symbol on what was presumably the upper surface of the stone. The other $(\mathrm{Pa} 27)$ which was found in the same area, has a three-line inscription arranged right to left in an overall horseshoe shape; it starts with the middle line, then moves on to the bottom line and then on to the top line. It is written as on a continuous baseline, which in this case results in the letters of the bottom line (line 2) being upside down in relation to those of the upper two lines (lines 1 and 3). Reading these inscriptions would involve walking round the stone, bending and head and eye movements.

\section{Discussion}

What emerges most obviously from this survey is the variety found both in the types of monument and in the arrangement of the inscriptions. As we have seen, the inscriptions are not presented in a 'user-friendly' manner, at least from a modern perspective, often requiring the reader to walk, bend and move the head and eyes in ways unfamiliar to us today. The arrangement of the inscription seems to be constrained by the nature of the monument: the size and shape of the stone and the placing of the decoration, where present. It seems reasonable to deduce that the primary choice made was of the stone, with the inscription being a secondary consideration. This argument is supported by the fact that uninscribed versions of all the main monument types are attested and, except in the case of the Paduan stelae, the uninscribed versions dominate numerically. While the inscription may have offered 'added value', to use another contemporary term, it was clearly not an essential component of the tombstone.

Having concentrated on the role of the reader so far, it is time to consider that of the writer, a term I use here to refer to the stone mason who carved the inscription (leaving aside the issue of who commissioned it or who composed it, whether the same person or a third party). We have no archaeological information about the production of the stones, but I make the assumption that they were produced in workshops, which would have had equipment that allowed the stones (few 
of which are outstandingly large or heavy) to be moved to facilitate the writing process, i.e. to be turned round or over. Thus the writer would have been able to write horizontally at all times, whatever the position or direction of the line in the final monument. Whether this was in fact the case could perhaps be elucidated by detailed study of the surfaces of the stones using a technique such as RTI (Reflection Transformation Imaging: see Earl et al. 2011; Piquette forthcoming; see also Piquette and Whitehouse, Figure 1, this volume), which could show up tool marks, and indicate direction, angle and depth of carving; however, no such work has been undertaken on the Italian monuments and this remains a project for the future. Most of the stones used for the monuments - limestone, sandstone and trachyte - are relatively soft and easy to carve, the exception being the porphyry of the ciottoloni, which is a hard volcanic rock. The inscriptions are generally carved competently, with well-formed letters of more or less equal size, constrained by bands designed to contain them. These bands are created between zones of decoration (in the Bologna and Rubiera stelae) or around the edge of a figured panel (in the Paduan stelae), or by the incision of straight lines (in the case of the Este cippi); even the more elaborate ciottoloni have such incised lines. There are no obvious mistakes of composition and the inscriptions in Venetic include punctuation marks, in the elaborate system developed for that script. None of the inscriptions mark word divisions (Venetic punctuation separates syllables) and no attempt is made to make word divisions coincide with edges or corners of stones: the continuous text carries on regardless.

Whether the stone masons composed the inscriptions themselves or copied from templates composed by others, it seems likely that they would have become competent at reading these short and simple texts. Whether this was also true of the readers is far less clear. To explore further what reading entailed at this time, we may try to outline the 'visitor experience' in an Iron Age cemetery in northern Italy. 'Visitor experience' is another contemporary concept, but I mean it here not in the sense in which it is used by museum and cultural heritage specialists, but in terms of the original visitor experience of those who encountered the monuments at the time they were erected or not long after. This inherently hypothetical exercise is made even more tentative by the lack of detailed archaeological contextual information available; nonetheless it is worth undertaking as it serves to focus on one key concern of the current volume - that is the material practices involved in the consumption of writing. The only assumptions I make are that the monuments were standing in the open on or near the tombs, which were usually arranged in cemeteries, and that visibility was not impeded by the presence of buildings or, for that matter, shrubs or trees (which, of course, we do not know).

The monuments are relatively small. While the largest of the Bologna stelae may have been 207 $\mathrm{cm}$ tall when complete, this was exceptional: most of the stones were under $150 \mathrm{~cm}$ tall, many less than $100 \mathrm{~cm}$, and some no more than $50 \mathrm{~cm}$ - a range not unlike that to be found in a traditional English churchyard. When standing, particularly in groups in a cemetery, they would probably have been visible from a few hundred metres away, but would not have appeared very impressive at this distance. As one approached, the stones would have appeared larger and the presence of decoration would have become apparent, though details of scenes would not have been clear until one was quite close to the monument. What about the inscriptions themselves? The heights of the letters ranges from c. 3 to 8 or $9 \mathrm{~cm}$. To help us visualise this, it is worth noting that the larger size is close to that of UK car number plates, which the British driving test requires drivers to be able to read at a distance of $20.5 \mathrm{~m}$ (Driving Standards Agency 2013) - and quite a lot larger than found on most tombstones today. Script with letters $3 \mathrm{~cm}$ high, much more comparable to that of modern tombstones, can be read at about half that distance in average daylight. Whether these distances would have applied in the case of the Iron Age tombstones is unclear. It is one thing to read black letters standing out against a white or yellow background, quite another to make out letters inscribed in stone. There is some evidence that some of the inscriptions may have been painted or infilled with coloured matter, but we do not know how widespread this practice was or how long such colour would have survived on stone surfaces or in incisions or carved depressions 
in stones left out in the open. In practice the inscriptions would probably have been read from a position quite close to the stone, much as we read tombstones in a churchyard today, a quite intimate experience. Where the Iron Age experience would have differed from the modern one is in the bodily engagement involved. Whereas we would tend to stand, or perhaps sit or kneel, in a stationary position in front of the gravestone, the Iron Age visitor would have been prepared to walk round the monument, to bend and to twist their head from side to side and back again, or perhaps to undertake more difficult bodily contortions, if they wished to read the inscription in its entirety. Since bodies vary in size and agility, these movements would have been easier for some than others. The young and able-bodied could have accomplished them reasonably easily, whereas the old, arthritic or pregnant would have encountered greater difficulty. Interestingly, the people who would have been able to read them most easily (from a corporeal point of view) were children: not only would they have been more agile generally, but they would not have had to stoop to read them.

The question that arises is whether Iron Age people did indeed undertake this bodily engagement, or whether it sufficed to know that the inscription was present, that the tombstone had been completed in this way. This leads onto the question of who the expected reader was. Calculations of the proportion of literate people in ancient cultures are difficult to make (see Harris 1989 for classic discussion of this subject, while Stoddart and Whitley 1988 and Cornell 1991 offer divergent opinions on ancient Italy), but it is always assumed that the figures were very low and there is no reason to believe that northern Italy in the Iron Age was any exception. So, the number of people who could have read the inscriptions was probably small, although they would presumably have been concentrated in the elite families that erected the more elaborate tombstones and had greater access to education. We need to ask also whether the inscriptions were intended exclusively for the time they were erected and for the people who commissioned them, presumably the family of the deceased, or whether they were also intended for posterity and for viewing by strangers, as we know was the case with many Roman funerary inscriptions (see, for example Carroll 2009). In the absence of explicit references in the inscriptions themselves, which sometimes occur in the Roman examples, there is no way we can answer this question, but it does affect our conclusion about the intended readability of the inscriptions. For the family and friends of the deceased, and anybody else present at the funeral, the identity of the deceased was known and would not have had to be read from the stone, as would be the case for passing strangers or future visitors. While it is reasonable to imagine that the erection of a tombstone would always have had connotations of long-term survival and preservation of the memory of the deceased, this may not have involved any specific attempt to produce readable inscriptions for the future. The overall impression we gain is that the writers were concerned with producing texts containing the correct information and had little concern for their readability, either short- or long-term.

On the other hand, this impression may arise from unwarranted presentist assumptions about the nature of reading. In an examination of the materiality of writing in $1^{\text {st }}$-millennium BC Italy (Whitehouse 2008), I have looked at examples from a wide range of monuments and smaller artefacts found in several different areas of Italy. I have found that the characteristics described here in connection with the north Italian tombstones occur in many other cases too, not only on stelae, but also on portable artefacts such as pottery vessels, clay loomweights, bronze vessels, plaques and figurines, and jewellery items such as rings and fibulae made of precious metals (see also Perego, this volume). We find inscriptions running in many ways other than in straight lines: in loops, circles or spirals, for instance, or, three-dimensionally, continuously round the neck, body or base of a pottery or metal vessel or up the side of a figurine and across its shoulders (see Cessford, this volume, who also describes artefacts with writing arranged in several different ways, albeit from more recent contexts in the UK). To read such inscriptions requires a bodily engagement that is unfamiliar to us as modern readers, though in the case of the portable artefacts it would probably have involved turning the object in the hands rather than more dynamic movement of the eyes, 
head or body, as it would in the case of the stelae and other fixed monuments. In any case reading in the Iron Age would have been not just a cerebral but also a physical experience, in a way that is unfamiliar to us today.

So - what can we conclude in relation to the Iron Age tombstones? On the one hand, the writers seem not to have been concerned primarily with producing readable texts, but with including the necessary information (mainly the name, and sometimes the status, of the deceased) in the available space. This information may have been perceived as necessary as much for the world of the dead (the deceased individual, familial ancestors and divine beings) as for the world of the living. On the other hand, in the world of the living, among visitors to the cemetery, though not many people would have been able to read the inscriptions, those that could would have expected to engage with the monuments in a corporeal way and would not have found it strange to bend, twist and walk round them in order to read what was written on them. By taking a material practice approach, we can understand better both the production and the consumption of the written texts in terms of the human body, the capacities and limitations of its motor skills and the functioning of its senses. We can appreciate the effects that the differences between human bodies might have - whether arising from size, age, condition or specific ability / infirmity - and understand how they might have affected the processes of 'reading' and 'writing. We have already noted how 'reading, in the corporeal sense described here, might have been easier for children with their more agile movements, better eyesight and viewpoints closer to the ground; by contrast 'writing' in the same sense might have required the more developed motor skills and physical strength of healthy adults. These corporeal abilities might have had little connection to the cerebral skills required to understand the linguistic content of inscriptions ('reading' and 'writing' as these terms are more usually understood); however they were certainly relevant to the ways in which the tombstones were produced and consumed and therefore to the way they functioned in society.

\section{Notes}

1 The terms stele (Greek; the Italian version is either stela or stele) and cippus (Latin; the Italian version is cippo) are both used to describe standing stones. I have been unable to find definitions that separate them consistently, although there is a tendency to use stele for rectangular stones with flat faces and cippus for other shapes, such as cylinders or obelisk shapes. In this chapter I use the terms traditionally employed for the particular monuments in question. The Italian term ciottolone means literally 'big pebble', which is an accurate description of this type of monument.

\section{References}

Balista, C. and Ruta Serafini, A. 1992. Este preromana: Nuovi dati sulle necropolis. In Tosi, G. (ed.), Este Antica: dalla preistoria all'età romana. Padua: Zielo, 111-123.

Calzavara Capuis, L., Martini Chieco Bianchi, A. M. and Prosdocimi, A. L. 1978. Due nuovi ciottoloni con iscrizione venetica. Studi Etruschi 46: 179-203.

Carroll, M. 2009. 'Vox tua nempe mea est': Dialogues with the dead in Roman funerary commemoration. Accordia Research Papers 11 (2007-2008): 37-76.

Cornell, T. J. 1991. The Tyranny of the Evidence: A discussion of the possible uses of literacy in Etruria and Latium in the archaic age. In Literacy in the Roman World (Journal of Roman Archaeology Supplementary Series Number 3). Ann Arbor, RI: Department of Classical Studies, University of Michigan, 7-33.

De Simone, C. 1992. Le iscrizioni etrusche dei cippi di Rubiera (Archaeologica Regiensia 6). Reggio Emilia: Comune di Reggio Emilia. 
Driving Standards Agency 2013. The Official Highway Code. London: HMSO (Her Majesty's Stationery Office).

Ducati, P. 1911. Le pietre funerarie felsinee. Monumenti antichi dei Lincei 20: 360-724.

Ducati, P. 1943. Nuove stele funerarie felsinee. Monumenti antichi dei Lincei 39: 374-446.

Earl, G., Basford, P. J., Bischoff, A. S., Bowman, A., Crowther, C., Hodgson, M., Martinez, K., Isaksen, L., Pagi, H., Piquette, K. E. and Kotoula, E. 2011. Reflectance Transformation Imaging Systems for Ancient Documentary Artefacts. Electronic Visualisation and the Arts, July, London. http://ewic.bcs.org/upload/pdf/ewic_ev11_s8paper3.pdf [accessed 21 October 2013].

Fogolari, G. 1988. La cultura. In Fogolari, G. and Prosdocimi, A. L. (eds), I Veneti Antichi: Lingua e cultura. Padua: Editoriale Programma, 1-225.

Harris, W. V. 1989. Ancient Literacy. Cambridge, MA: Harvard University Press.

Lomas, K. 2006. The Stele of Ostiala Gallenia: Funerary commemoration and cultural identity in northeast Italy. In Herring, E., Lemos, I., Lo Schiavo, F., Vagnetti, L., Whitehouse, R. and Wilkins, J. (eds), Across Frontiers: Etruscans, Greeks, Phoenicians and Cypriots: Studies in honour of David Ridgway and Francesca Romana Serra Ridgway. London: Accordia Research Institute, 451-462.

Marinetti, A. 1992. Este preromana: Epigrafia e lingua. In Tosi, G. (ed.), Este Antica: dalla preistoria alletà romana. Padua: Zielo, 127-172.

Martini Chieco Bianchi, A. M. and Prosdocimi, A. L. 1969. Una nuova stele paleoveneta iscritta. Studi Etruschi 37: 511-514.

Meller Padovani, P. 1977. Le stele villanoviane di Bologna. Capo di Ponte: Edizioni del Centro.

Piquette, K. E. forthcoming. Reflectance Transformation Imaging: A new method for the digitisation and study of early Egyptian graphical culture. In Graff, G., Jiménez-Serrano, A. and Bailly, M. (eds), Préhistoires de lécriture: iconographie, pratiques graphiques et émergence de l'écrit dans l'Egypte prédynastique / Prehistories of writing: Iconography, graphic practices and the forming process of writing in Predynastic Egypt. Actes de la table-ronde de décembre 2010. Aix-enProvence: Préhistoires méditerranéennes.

Prosdocimi, A. L. 1988. La lingua. In Fogolari, G. and Prosdocimi, A. L. (eds), I Veneti Antichi: Lingua e cultura. Padua: Editoriale Programma, 225-422.

Scarfi, B. M. 1969-1970. Altino (Venezia): Le iscrizioni funerary romane provenienti dagli scavi 1965-1968 e da rinvenimenti sporadici. Atti dell'Istituto Veneto di Scienze, Lettere ed Arti 128: 207-89.

Stary-Rimpau, J. S. 1988. Die Bologneser Stelen des 7. bis 4. Jh. v. Chr. Marburg: Phillipps-Universität. Stoddart, S. and Whitley, J. 1988. The Social Context of Literacy in Archaic Greece and Etruria. Antiquity 62: 761-772.

Whitehouse, R. 2008. The Materiality of Writing: Case studies from $1^{\text {st }}$ millennium BC Italy. McDonald Lecture, 19 November 2008, Cambridge (being prepared for publication).

Whitehouse, R. and Wilkins, J. 2006. Veneti and Etruscans: Issues of language, literacy and learning. In Herring, E., Lemos, I., Lo Schiavo, F., Vagnetti, L., Whitehouse, R. and Wilkins, J. (eds), Across Frontiers: Etruscans, Greeks, Phoenicians and Cypriots: Studies in honour of David Ridgway and Francecsa Romana Serra Ridgway. London: Accordia Research Institute, 531-548.

Zampieri, G. 1994. Il Museo Archeologico di Padova. Milan: Electa. 